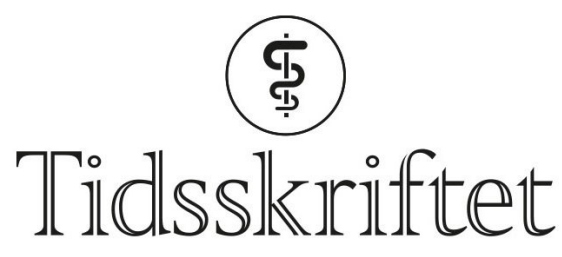

DEN NORSKE LEGEFORENING

\title{
Mye feilmedisinering etter sykehusinnleggelse
}

FRA ANDRE TIDSSKRIFTER

KETIL SLAGSTAD

Tidsskriftet

Mange pasienter som skrives ut fra sykehus, blir stående på legemidler som kan være skadelige.

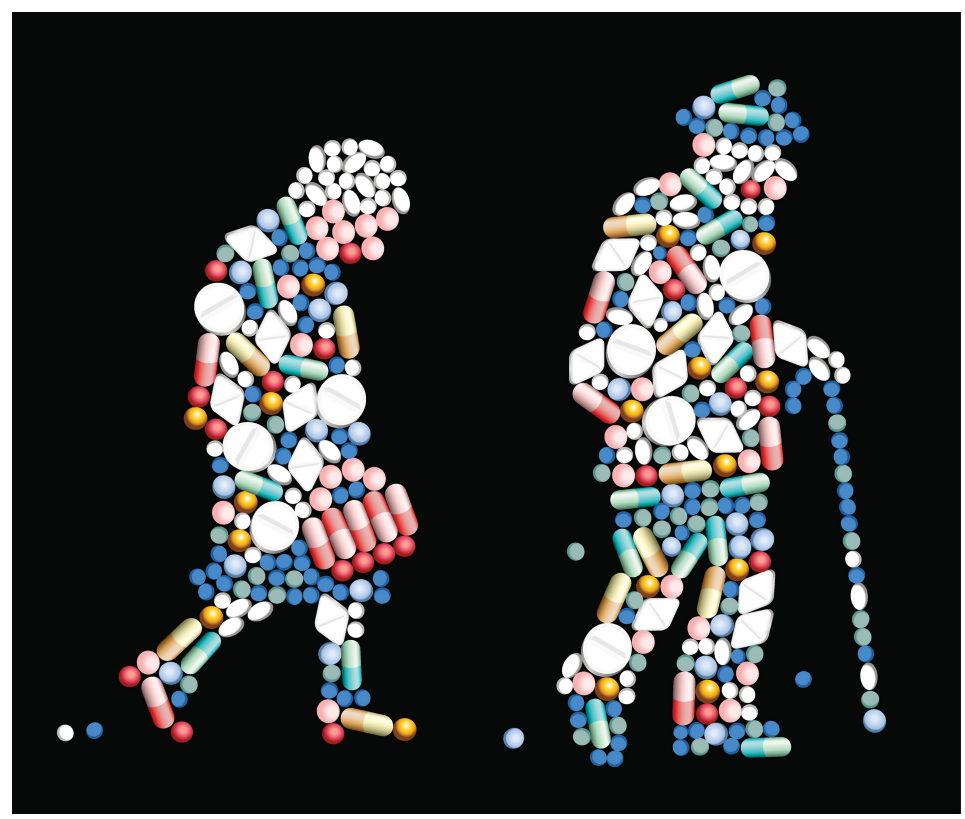

Illustrasjon: iStock

I en studie som nylig er publisert i tidsskriftet $B M J$, undersøkte forfatterne sammenhengen mellom sykehusinnleggelser og risiko for feilmedisinering og overmedisinering (1). Studien var basert på journalopplysninger fra irske allmennlegekontorer for flere enn 38 ooo pasienter over 64 år for perioden 2012-15.

Opptil $15 \%$ av pasientene hadde minst én sykehusinnleggelse per år. Forekomsten av potensielt skadelig medisinering, bedømt med et anerkjent skåringsverktøy, varierte fra 45,3 \% i 2012 til 51,0 \% i 2015. Blant de hyppigste risikoforskrivningene var over åtte ukers behandling av magesår med protonpumpehemmer i full dose, benzodiazepinbehandling i minst fire uker og forskrivning av legemidler over anbefalt behandlingslengde, spesielt sovemidler utover fire uker. Sammenlignet med pasienter uten sykehusinnleggelse hadde pasienter som ble innlagt på sykehus, økt risiko for potensiell skadelig forskrivning (hasardratio 1,24; $95 \%$ KI 1,20-1,28). Pasienter som ble hospitalisert, hadde betydelig $ø \mathrm{kt}$ 
risiko for skadelig forskrivning etter utskrivning sammenlignet med før innleggelsen (oddsratio 1,72; $95 \%$ KI 1,63-1,84).

- Polyfarmasi er et voksende problem, også i Norge, sier Anders Grimsmo, som er professor ved Norges teknisk-naturvitenskapelige universitet. - I Norge viser studier at rundt $20 \%$ av hjemmeboende over 70 år bruker ti eller flere legemidler. Omlag en tredel av alle sykehusinnleggelsene for personer over 80 år er forbundet med legemiddelproblemer, sier Grimsmo.

Dagens legemiddellister beslaglegger økende ressurser i kommunene, sier Grimsmo, som påpeker at polyfarmasi kan føre til kognitiv reduksjon og skrøpelighet som fremskynder behov for hjemmesykepleie og sykehjem. Avmedisinering kan bedre funksjonsevne og livskvalitet og øke overlevelse. Derfor er det viktig at sykehusleger før utskrivning går nøye gjennom legemiddellisten for å sjekke om hvert forskrevet legemiddel er nødvendig, sier Grimsmo.

\section{LITTERATUR:}

1. Pérez T, Moriarty F, Wallace E et al. Prevalence of potentially inappropriate prescribing in older people in primary care and its association with hospital admission: longitudinal study. BMJ 2018;363: k4524. [PubMed][CrossRef]

Publisert: 21. februar 2019. Tidsskr Nor Legeforen. DOI: 10.4045/tidsskr.19.0070

(C) Tidsskrift for Den norske legeforening 2020. Lastet ned fra tidsskriftet.no 